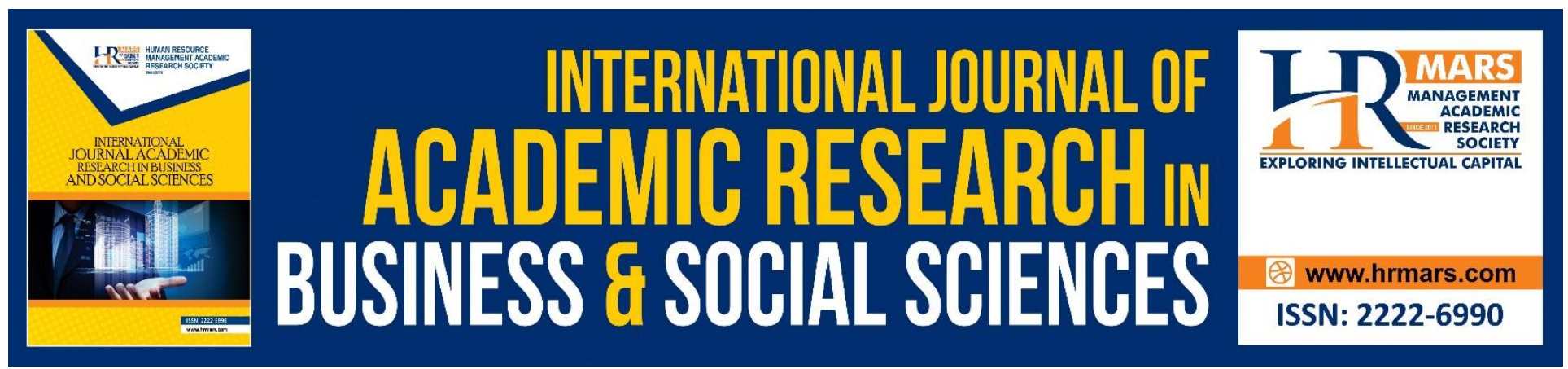

\title{
Islamic Diplomatic Mechanism in Malay Sultanate Letter
}

\author{
Salmah Jan Noor Muhammad
}

To Link this Article: http://dx.doi.org/10.6007/IJARBSS/v8-i8/4616

DOI: $\quad 10.6007 /$ IJARBSS/v8-i8/4616

Received: 06 July 2018, Revised: 23 July 2018, Accepted: 29 July 2018

Published Online: 18 August 2018

In-Text Citation: (Muhammad, 2018)

To Cite this Article: Muhammad, S. J. N. (2018). Islamic Diplomatic Mechanism in Malay Sultanate Letter. International Journal of Academic Research in Business and Social Sciences, 8(8), 596-607.

Copyright: (C) 2018 The Author(s)

Published by Human Resource Management Academic Research Society (www.hrmars.com)

This article is published under the Creative Commons Attribution (CC BY 4.0) license. Anyone may reproduce, distribute, translate and create derivative works of this article (for both commercial and non-commercial purposes), subject to full attribution to the original publication and authors. The full terms of this license may be seen at: http://creativecommons.org/licences/by/4.0/legalcode

Vol. 8, No. 8, August 2018, Pg. 596 - 607

http://hrmars.com/index.php/pages/detail/IJARBSS

JOURNAL HOMEPAGE

Full Terms \& Conditions of access and use can be found at http://hrmars.com/index.php/pages/detail/publication-ethics 


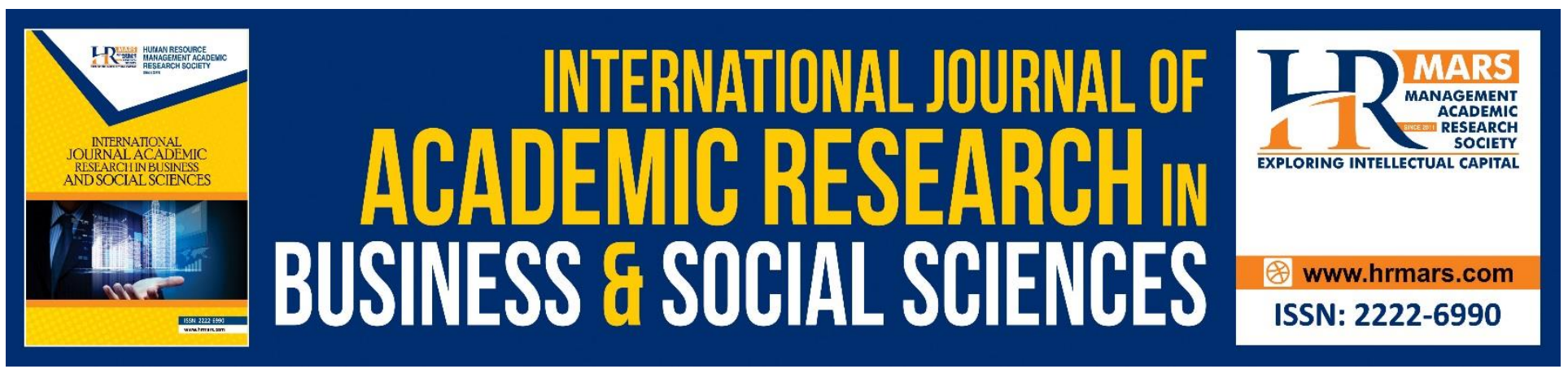

\title{
Islamic Diplomatic Mechanism in Malay Sultanate Letter
}

\author{
Salmah Jan Noor Muhammad \\ Department of Malay Language, Faculty of Modern Languages and Communication, Universiti Putra \\ Malaysia, Malaysia
}

\begin{abstract}
Malay Sultanate letter is Jawi hand-written text that possesses the splendid and attractive illmumination. It was incumbent upon the goverment officials to send it to the other governments. This letter was authored by a palace writer as in tandem with the missions of the monarch of the kingdom. Often time, through this letter, the monarch has come to an agreement to establish a diplomatic relation. In this sense, the question that might be raised is that what 's interesting and the highlight of the Malay Sultanate letter that capables of establishing a diplomatic relationship between kingdoms? Through the meticulous observations upon some selected letters from Malay Sultanate, the most apparent things figured out was the arrangement of letter contents that bear the Islamic doctrine elements. Therefore, the objective of this study is to identify and describe the Islamic diplomatic mechanism that was practiced by the government officials to establish diplomatic relationship with other governments. Hence, this research finding is hopefully meaningful and helpful to all political science and diplomatic relation institution reseachers in approaching the study of international relation practices in ancient governments.
\end{abstract}

Keywords: Mechanism, diplomacy, Islam, letter, Malay Sultanate

\section{Introduction}

Diplomacy is a kind of relationship involving between countries that is peace in nature. Afzal lqbal (2000) stated that diplomacy is a means to reach the aims and genuine, clean agreement in a relationship. This fact has been advocated by Bijan Bidabad (2012) and Salmah Jan Noor Muhammad (2017) saying that diplomacy is a skill or art in negotiation to come to an agreement at international level. Meanwhile, Keith Hamilton and Richard Langhorne (2011) opined that diplomacy is in a world where war is everybody's tragedy and everybody's nightmare, diplomacy is everybody'd business. Therefore, diplomacy is a kind of relationship that put the spirit of integration as a hefty charge that involves two or more countries to initiate an agreement to fulfill their respective needs. In Malay Land, there were many Malay Sultanate kingdoms. Among of them were Malacca Sultanate, Kedah Sultanate, Johor-Riau-Lingga Sultanate and Acheh Sultanate.

Those sultanates were renowned with their exceptional quality in excellent governance of kingdom. Many was discussed in the past literatures about Malay Sultanate such as Muhammad 
INTERNATIONAL JOURNAL OF ACADEMIC RESEARCH IN BUSINESS AND SOCIAL SCIENCES Vol. 8, No. 8, August 2018, E-ISSN: 2222-6990 @ 2018 HRMARS

Yusoff Hashim (1992), Mohd Jamil Mukmin (2011), Ahmad Jelani Halimi (2008) and Ahmat Adam (2016) who recognized the excellence of Malay Sultanate. All these scholars were in a consensus on the fact that Malay Sultanate were skillful in kingdom governance. In this sense, the strong diplomatic relationship becomes a factor of a good governance. Diplomatic relation is one of the vital aspects for a kingdom to propagate its influence as well as to strengthen the political, economic and social aspects. Mohd Jamil Mukmin (2011) said that the main aim a kingdom establishing diplomatic relationship with gigantic kingdoms such as China and Majapahit is due to avoid the threats from anemies that might affect the domestic governance and country affairs. The failure in establishing diplomatic relationship catalysts the strong kingdoms to announce colonialism over others. Therefore, the government leaders would take initiatives to utilize the best mechanism in ensuring the sustainable diplomatic relation possible. Among the mechanism used for that purpose is through mail delivery.

\section{Literature Review}

Adib Imran (1999) opined that letter is a means of relationship between anemies or friends as a link of government. Whereas, Siti Mariani S.M Omar (2001) asserted that letter is among the earliest manuscripts produced by ancient people for many purposes and importance. Researches pertaining to the Malay Sultanate letter were studied by several researchers. One of them is Mahfuzah Yusuf (1994) who studied the contents of Malay letters. According to her, letter signifies civilization and Malay arts. Her assertion has been supported by La Niampe (1996) who studied the letters from Butom Kingdom from XVII-XIX decade in which the art of the letter lies in its splendid writing and the use of its subtle language. This resembles the rank and quiddity of the sender. The contents of the king's letter are important to be the primary source in the historical construct observation purposely either for diplomatic relation or politic and economy. Abd Razak Abd Karim (2015) also said that Malay letter possesses high internal aethetical essence. The art resembles the culture of the Malays in producing a letter.

On the other note, Noor Suraya Adnan (2008) has made comparative study on the letters collection owned by Sir Francis Light with the collection of letter owned by Sultan Abdul Hamid Halim Shah from the aspect of language. She has chosen 12 letters from the collection from 1786-1794 and 1886-18894 written by Malay kings and English and Siam governors. The findings revealed that there was the change of language use in the royal letter, for example, there was a code switching and code mixng in the royal writing language when there was a political pressure. However, according to her, the change is temporary in nature because the kings wrote in their language again according to the sovereignty hierarchy when they wrote letters to their colleagues who were closer and more pleasant to them without pressure. Research by Lina Abdullah \& Dzul Haimi Md Zain (2011) otherwise studied the design of the Malay Archepelago letter. The finding revealed that the letter possesses the hidden geometrical structure or symmetrical dynamic based on the methematical calculation that make the whole contents of the letter are highly and beautifully aesthetical.

Salmah Jan Noor Muhammad (2017) also discussed about Malay letter. She asserted that the palace writers have played the great role in mail delivery. The findings showed that there was a close relationship between writers and kings and this become one of the pulling factors for the writers to really translating the messages of the kings into the writing of the letter. This relationship would be able to produce exceptional letter write up that could bring the good impact especially to the government's diplomatic relationship. The significance lies in the way that intellectual collaboration and compatibility through emotional approach between two parties would sinergize the excellent 
writing of letter that is inevitably high in its quality. Apart from this, Isnariah Idris, Khushairi Fadzal, Abdul Rashid Daing Melebek (2017) have studied the values encoded in ancient Malay letter in 19th decade. They used the sampling technique, category, measurement system, note unit and context unit in identifying the Malay values encoded in the letter. The finding showed that there were eight values which were compliance to the just, noble and honest leaders, high courtesy and ethics in speech and action, respect and be altrustic in relationship and when with guests, give and take, love and care, honesty and sincerity, positive assumption among human beings and integrity. For them, the eight items of values have elevated the nobility of Malays in the eyes of the outsiders.

Ab. Razak Ab. Karim \& Reniwati (2017) focused on the illumination of the letter dated from year 1521-1899. They stated that there were lighting and caligraphical use in Malay letter that used the coloured pictures with leaves and flowers as the motives such as cloves, frangipani, lilies, and jasmine. Moreover, geometrical shapes were so popular and widely used as the illumination of the letter. Ab Razak and Reniwati said that those illumination are the symbols of creativity of Malay people in which the illumination highlight that fact that Malays are skillful in crafting and letter decoration. Writing by Gallop, Annabel Teh (2018) otherwise focused on the royal seal. They asserted that the royal seals were belong to sultans or kings that become the most valuable source for the kings' reputation besides encompass the important details that were not stated in the delivered letetr. Apparently, through these prolific researches, there is a great contribution of suppying the important information to society. However, Ab. Razak AB Karim (2005, 2006, 2016 \& 2017) a prolific researcher in the course of Malay letter often times emphasized the scarcity of literatures in the field of Malay letter among the scholars despite of the myriad of things that can be put forth for public use. For instance, cultural, artistic and other aspects were oftentime shown in Malay Letters. Saiful Bahri Kamaruddin (2015) has put forth the same concern where he alarmed that Malays are condemned to be in regretfulness in the future if the study on ancient Malay manuscript especially letter is put in silence. From the urgency made by those scholars, this paper will focus on the Malay Sultanate letter as a main discourse.

Revisting the past researches, scholars are more focused on the physical forms of a letter such as the illumination, design and seal of the sultans. Hence this writing will further develop a study on the subject by studying it from the Islamic diplomatic mechanism. This is because Islam was founded in the archipelago estimated at 225 Hijriah equivalent to $840 \mathrm{M}$ in Perlak (Hashim Musa, 2004). Syed Muhammad Naquib al-Attas (1972: 21) said that Islam has brought the spirit of rationalism and intellectualism not only among the members of the palace but also to its roots; citizens. Ali Ahmad, Siti Hajar Che Man and Jelani Harun (2005) also asserted that Islam has its own rationality or philosophy of thinking in nurturing the use of their minds. The influence of Islam was reinforced when Prophet Muhammad s.a.w was the first to send the diplomatic letter to teh King Heraclius (Rom), King Khosrau II (Persia), Governor Al-Munzir bin Sāwī (Bahrain) and Al-Muqawqis (Egyptian state leader). Islam is inherently blended in the life of the Malay government leaders. Hence, this article will identify and elaborate the mechanism of Islamic diplomacy practiced in the Malay sultanate's texts.

\section{Research Methodology}

This study employed the library method to collect the necessary data. There are four levels that have been planned, namely the level of selecting, collecting, analyzing and formulating data. At the optimum level of data, the emphasis was on the selection of the Malay sultanate. This level was an important step in obtaining the overall idea of the discussion. Furthermore, at the stage of data 
collection, observation was conducted upon the the letters corresponding to the objectives of the study that have been identified. Each reading of the contents was reviewed and noted, especially the information that discusses the topic of the study. Meanwhile, at the level of data analysis, the focus was on the information obtained from the second stage and was used as the main material in discussing the findings of the study. As a result of this data analysis, a summary of findings was made available to elaborate the mechanism of Islamic diplomacy in the Malay Sultanate's text.

Additionally, in order to establish a description of the study, the theory of Islamic diplomacy was used. The Islamic diplomacy theory was introduced by Wang Yong Bao (Ahmed Musa) as a result of his research on the practices and patterns of diplomacy applied by Prophet Muhammad s.a.w and his companions. This book of Islamic diplomacy theory was published in 2009. In this theory, Wang Yong Bao (Ahmed Musa) emphasized the procedures used by Rasulullah when he sent a letter to the surrounding kingdoms. First, the diplomatic letter begins with the name of God. Second, state the name of the conveyor and his office. Third, use the courtesy call and address to the recipient. Fourth, greeting and fifth, letters endorsement with special stamps.

According to Wang Yang Bao (2009), this Islamic diplomatic mechanism emphasizes ethical, civilized, polite, and ethical elements. It is important to avoid misunderstandings among the parties to the letters. In addition, this theory also concerns the good relations between one country and one anothers and resolves any dispute taken place if it is not based on feelings of emotion and envy. Therefore, this theory is very suitable to be the main foundation in discussing the topic of study.

\section{Findings}

\section{The Use of Arabic Expression in the Letterhead}

The Islamic diplomatic mechanism identified in the Malay sultanate's paper is the use of Arabic language in the letterhead. The letterhead is a brief expression written in Arabic and located at the very top of the letter and is written with quite interesting writings with various forms such as boats and so forth. In a letter, the letterhead has a certain connotation that a transmitter attempts to describe (Ab Razak Ab Karim, 2005). Often, the words used are like Al-fattah (opener), Qawluh alHaqq (the words of truth), Ya Ghafur Rahim (The Merciful and All-Forgiving) and Al-Wahid al-Karim (The Oneness of God and The Most Gracious). For example, Sultan Iskandar Muda's Letter from Aceh sent to King James I, in 1615 had used the letterhead with the expression Al-Hamd li'llah Rabb alAlamin, Yā 'Aziz Yā Ghaffār. Likewise with the Tunku Tua Letter from the Siak government to Thomas Stamford Raffles in 24th Zulhijah 1225/ January 20, 1811 has used the word Qawluh al-Haqq on the letterhead.

The use of the Arabic expression and the name of Allah were intended to inform the receivers that the government who sent the message is a Muslim. God's name is used to describe the life of Muslims that always depend only on God. Without His permission and redemption, it is impossible for human beings to be held, especially in diplomatic affairs which is an important part of the administration of the government. This is in line with the theory of Islamic diplomacy which emphasizes the use of the name of Allah as the main principle.

\section{Decency of Language}

Decency of language reflects on one's behaviors. Nurjamily (2015) argues that language decency is a behavior that is expressed in a good or ethical manner. Wan Robiah Meor Osman \& Hamidah Abdul Wahab (2018) stated that language politeness was measured based on the selection and use of language by the speakers who are complying to the code of ethics or rules standardized in the 
language of a society. It refers to the use of good language, polite, civilized, exalted noble personalities and shows respect to other counterparts. Therefore, language decency refers to the attitude and the communicative speech of a society that does not offend others. The language decency in the Malay text is to state the name and position, the use of courtesy call and greetinf for recipient. These three things are mentioned at the beginning of the paragraph of a letter. In addition, the word of praise to the recipient is also categorized as a form of language decency and its position is also at the beginning of the paragraph of the letter. The Islamic diplomacy theory states that the name of the conveyor and his office, said the call of salutation and the salutation of the recipient is the procedure to be specified in a letter and it is a symbol of Islam. Gallop, Annabel Teh (1994) argued that it is a reflection of the Malay art of letters resembling the majesty and excellence civilization under the Malay Sultanate and shows that Malay civilization is proficient in correspondence arrangements. For example, Sultan Ibrahim's Letter from Selangor to the Governor [F. Light] on 6th of May 1200th equivalent to April 6, 1786.

"Bahawa ini warkat al-ikhlas yang terbit daripada hati putih lagi jernih iaitu daripada hadrat Maulana Sultan Ibrahim Raja yang memerintah di dalam negeri Selangor Darulkhusus barang disampaikan Tuhan seru sekalian alam kepada sahabat kita Gubernadur Mister Light yang memegang perintah Kompeni Inggeris di dalam bandar kota Pulau Pinang, yang telah masyhur namanya kepada segala negeri yang di barat dan negeri yang di timur dan lagi mengasih orang miskin dan anak dagang yang keluar masuk di dalam bandarnya."

[Hence this letter of sincerity whence it came from the pure virtuous heart of His Majesty the Maulana Sultan Ibrahim, King of Selangor Darulkhusus, is delivered by God to call upon all creatures of the realm towards our friend Governor Mister Light who holds command of the English Company in the city of Penang, whose name bears glory in all the lands in the West and the East, and whose compassion is endless for the poor and the wanderers in the city.]

(Source: Gallop, A.T., 1994:202)

Through the example above, it is clear that Sultan Ibrahim has declared the name of the recipient, Francis Light, who was the Governor of Penang. Sultan Ibrahim also gave praise to Francis Light by mentioning that Francis Light is a well-known person with compassion for the poor and allowing foreign traders exercise in Penang. The word praise is a language act, which is a meaningful phatic communion (Abdul Razak Abdul Karim, 2006). The Malay sultanate will surely choose and use good and courageous words. In addition, sincerity is an example of the greetings given by the sender to the receiver. This is because the teachings of Islam itself emphasize the nature of sincerity in every created relationship. In addition, the importance of communicating well and not pride will create intimacy and mutual respect between one another.

\section{Seal for Self-introduction}

Seal is a special sign that has the name of a sultan and it is the fifth principle in the theory of Islamic diplomacy. Prophet Muhammad used his silver ring to be a seal. In 628 AD, Prophet Muhammad s.a.w used a seal when writing to the Emperor Byzantium. This is because the Byzantine Emperor will only 
INTERNATIONAL JOURNAL OF ACADEMIC RESEARCH IN BUSINESS AND SOCIAL SCIENCES Vol. 8, No. 8, August 2018, E-ISSN: 2222-6990 @ 2018 HRMARS

read the sealed letters. The seal of the Prophet Muhammad Pbuh engraves the word Muhammaad Rasulullah. In the Malay lands, the crown of Sultan Alauddin Syah (1589-1604) from Aceh is the first identified seal. He has used a seal written in Arabic at the letter sent to Harry Middleton in 1602. Subsequently, the second seal was used by Kimalaha Abdul Kadir from Ambon when he sent a letter to the Governor of the East Indies Company on May 23, 1658.

Sultans' seals have various styles and shapes. According to Gallop \& Annabel Teh (1994), the seal of the sultans has eight petals and within the petals, there is the name of the sultan, the sultan's name in Arabic and the year of the sultan's reign. In addition, there are also round shaped seal decorated with floral motifs. Islamic expressions such as al-wāthiq bi-gāh (People who hold fast to Allah), and zill Allāh fí al-'Amām (Shadows of God on earth), are also used in the seal. For example, the signing of Sultan Bima to Baron Van der Capellan dated October 7, 1823 had used an eighth and oval-shaped seal. In addition, the seal position also has its own meaning. Dulaurier (1845) said that a seal on the right to the right indicates that the sender has a higher status than a receiver while a stamp above the mark is likely to be written more than one sender and the left stamp indicates a low status sender. The seal position of the Prophet Muhammad s.a.w is located at the end of the letter cover. Here is a list of important components of a letter.

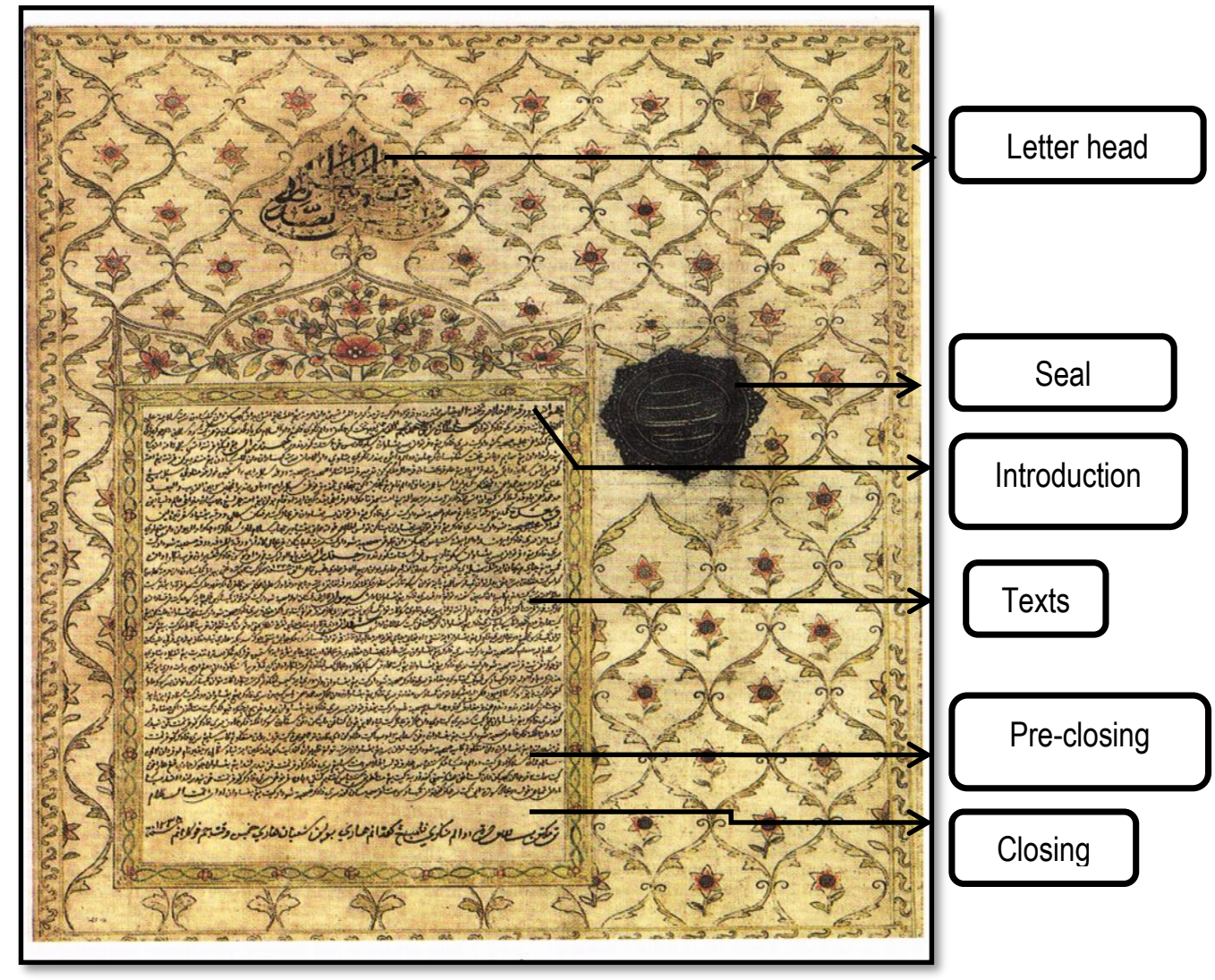

figure 1: Important Components of the Letter (Source: Mu'jizah (2009)

\section{Gift}

Prophet Muhammad Pbuh. Was once said, "Exchange gift, and establish together a good relationship" (Al-Sana'ani,1379:85). In Chapter Al-Naml, it was told a story of Bilqis, the princess of Sheba who has sent and brought a gift to Prophet Solomon and it was a great example of gift exchange between the leaders of kingdoms. Moreover, it was narrated before the decease of Prophet 
Muhammad Pbuh as he has ordained to all Muslimeen to consider this mechanism to establish the diplomatic relation with other countries. As narrated by Ibn Abbas as Prophet Muhammad Pbuh had said on the last day of his life, "..give (gift to) the representative a gift as what I did to them.." (AlBukhari,1320 A.H/1902 M: 121). Apart from being listed as one of Prophet Muhammad's practices, king and country leader and other tribes were also sending gifts to Prophet Muhammad Pbuh. For instance, this was narrated by Imam Ali: Kisra (King of Persian) has presented a gift to Rasulullah and he receiived it; Qasyar (Rome) has sent Rasulullah a gift and he received it; and the kings sent presents and he received them all (Wang Yong Bao, 2009). Therefore, apart from those five theoretical principles of Islamic diplomacy, gift is also identified as a mechanism of Islamic diplomacy.

The governance of Malay Sultanate was also exercising the gift exchange when the government officials went abroad (outside the kingdom). Every letter sent will be accompanied with several presents. Gallop, Annabel Teh (1994) opined that a letter with gift signifies a new diplomatic relation is just established. Furthermore, gift exchange brings some specific meaning. For example, Sultan Iskandar Muda Johan Pahlawan Mahkota Alam (1590-1636), the king of Aceh Darussalam has sent his representative to Turkey (Rome) with a herb gift whereas the Turkey Uthmaniyyah's caliph reciprocated him with an artillery and military advisor to assist them to strengthen Aceh's army (Fadhlullah Jamil, 1984)

Morever, among the gifts presented were traditional weapons such as spear and badik. It was recorded in King Kedah's letter to Lord Minto dated on 26 Dzulkaedah 1225 / 23rd December 1810. Paduka Seri Sultan Ahmad Tajuddin Halim Syah ibn al-Marhum Paduka Seri Sultan Abdullah Mukaram Syah (King of Kedah) has sent a gift in term of traditional weapons such as badik and spear with a piece of gold clothing, a Malay traditional clothing to Lord Minto who was the king of Benggala kingdom.

"Maka tiadalah sesuatu hadiah beta kepada sahabat beta yang patut jadi permainan mata, hanyalah badik berterapang sebilah dan tombak sepasang sampak emas pakaian orang Melayu, ...

[For there is no gift that only should be gazed upon, there is only a knife with a gold chasing and a pair of spears with golden...]

(Source: Gallop, A.T., 1994:212)

Apart from this, animals were also used to be a gift such as horse. Horse resembled dexterity and freedom. Paduka Seri Sultan Ismail, Raja Bima had sent two kuda merah and kuda kembang to Baron van der Capellen. The kuda merah and a pair of kuda kembang refer to kuda renggong. The gift was stated in Sultan Bima' letter to Baron van der Capellen dated on 1st Safar 1239 equivalent to 7th October 1823.

Syahadan adalah Paduka Sultan dengan sekalian menteri akan mengzahirkan tanda tulus ikhlas beserta percintaan yang tiada berkeputusan, iaitu dua pasang kudah merah dan sepasang kudah kembang dua r-y-n dan satu bunggus lilin yang tiada dangan sepertinya.

[Therefore His Majesty the Sultan and all Ministers shall proclaim the sign of good faith and incomparable kinship, in the form of two pairs of red chesnut horses and a pair of $r-y-n$ horses and a packet of wax unlike any other.]

(Source: Gallop, A.T., 1994:224) 
INTERNATIONAL JOURNAL OF ACADEMIC RESEARCH IN BUSINESS AND SOCIAL SCIENCES

Vol. 8, No. 8, August 2018, E-ISSN: 2222-6990 @ 2018 HRMARS

Gift as an accompaniment is a proof that Malay Sultanate leaders were committed in establishing the diplomatic relation with other kingdoms. This is because the gift will strenghten the relationship to one another. The gifts presented were expensive and quality as symbol of respect and nobility towards the other kingdom leaders. Prophet Muhammad Pbuh encouraged us to grant gift to others and for us to receive it. "Do exchange presents, hence you will be loving to each other" (AlBukhari,1320 A.H). Therefore, gift is said to be an Islamic diplomatic mechanism that needs to be practiced for the sysmbol of continuity and sustainability in a diplomatic relationship.

\section{Summary}

Islamic diplomatic mechanism observed in the Malay Sultanate letter was complying to all the Islamic diplomacy principles. Islam lays down the simple ruling in diplomatic relation through teh arrangement of mail delivery. The arrangement is a guideline to government officials in writing the letter in correct and effective way. Normaisarah Othman (2015) convicted that Al-Quran and Sunnah have become the ultimate sources of the principles of Islamic teaching that underlie the course of establishing the diplomatic relation. Tika Dian Pratiwi (2017) supported this statement emphasizing that Islamic diplomatic principles are the most sufficient and effective means in resolving any problems because problem is communicated clearly and transparent. Therefore, Islamic diplomatic mechanism will provide clarity to the community of practitioners on the methods applied in the process of diplomatic relation establishment and as one of a means of mail delivery. Letter is a means of communication on behalf of the government officials to signify the desired aims with clarity and completely.

\section{Conclusion}

Islamic diplomatic mechanism inletter is one of the approaches practiced by Malay Sultanate government in order to establish a diplomatic relationship. This is in line with Prophet Muhammad Pbuh.'s tradition of letter sending to other governments outside Madinah. Among the Islamic diplomatic mechanisms found in Malay Sultanate letter were arabic expression at the letter head and language courtesy in addressing name and position, the use of courtesy call and conveying greeting to the receiver. Moreover, the seal and gift employed as Islamic diplomatic mechanism were also identified. All the mechanisms were exercised as the contents of the letter and make the letter to have its distinguished structures. Moreover, the government officials have followed all arrangement of mail delivery and it is in line with the tehory of Islamic diplomacy. By having this, it is believed to be helpful in providing guidelines and knowledge to diplomatic institutions and government ambassadors pertaining to the used sources of diplomatic relation during the ancient time of Malay Sultanate. Not to mention, it is hoped that the study on Malay Sultanate letter from different fields would further develop as a inheritant entity to the generations to come.

\section{Acknowledgement}

This acknowledgement goes to the Putra Grant Scheme, Universiti Putra Malaysia for its contribution in funding the research conducted by the writer.

\section{Corresponding Author}

Salmah Jan Noor Muhammad, Senior Lecturer Universiti Putra Malaysia, Malaysia,. 
INTERNATIONAL JOURNAL OF ACADEMIC RESEARCH IN BUSINESS AND SOCIAL SCIENCES

Vol. 8, No. 8, August 2018, E-ISSN: 2222-6990 @ 2018 HRMARS

Email: salmahjan@upm.edu.my

\section{References}

Ab. Razak, A.K. (2005). Warkah-Warkah Kesultanan Melayu Lama Koleksi Perpustakaan Negara Malaysia: Analisis Komponen dan Binaan Warkah. Jurnal Pengajian Melayu, 15, 183-201.

Ab. Razak, A.K. (2006). Warkah Melayu Lama. Kuala Lumpur: Dewan Bahasa dan Pustaka.

Ab. Razak, A.K., \&Reniwati. (2016). Kata Sapaan Separa Rasmi dalam Masyarakat Minangkabau Di Kabupaten 50 Kota dan Daerah Rembau : Suatu Kajian Perbandingan. Jurnal Antarabangsa Alam dan Tamadun Melayu (Iman),3 (1), 63-70.

Ab. Razak, A.K., \& Reniwati. (2017). Illumination and Calligraphy in Malay Letters. Jurnal Arbitrer, 4 (2), 76-85.

Ab. Razak, A.K. (2018). The Use of Seal in Early Malay Official Letters : A Personal Identity and Ethnic Culture. Jurnal Arbitrer, 5 (1), 1-7.

Adib, I. (1999). Warkah Lama Pengungkap Peradaban Bangsa. Dewan Budaya, 9, 24-25.

Afzal, I. (2000). Diplomasi Islam. Jakarta : Pustaka Al-Kautsar.

Ahmad, J.H. (2008). Sejarah dan Tamadun Bangsa Melayu. Kuala Lumpur: Utusan Publications \& Distributors.

Ahmat, A. (2016). Antara Sejarah dan Mitos Sejarah Melayu dan Hang Tuah dalam Historiografi Malaysia. Petaling Jaya: Strategic Information and Research Development Centre.

Al-Bukhārī. (1320 A.H). Al-Ṣaḥiḥ. Egypt: Al-Mațba 'ah al-Khayiriyyah.

Ali, A, Siti Hajar, C.M., \& Jelani, H. (2005). Tasawwur Islam dalam Kesusasteraan Melayu Tradisional. Mindef: Universiti Sains Malaysia.

Alina, A., \& Dzul Haimi, M.Z. (2011). "Mencari Keindahan dalam Rekabentuk warkah Melayu Nusantara", in Seminar Antarabangsa Warisan Nusantara dan Bicara Kraft Warisan. 9th-11th December 2011. Kota Kinabalu: Universiti Malaysia Sabah.

Al-Ṣana, A. (1379). Subl al-Salām Sharḥ Blūgh al-Marām min Adillah al-Ahkām (4th ed.) Beirut: Dār Ihȳā' al-'Arabī.

Bijan, B. (2012).Diplomacy principles: an Islamic Sufi approach-continuation. International Journal of Law and Management, 54 (6), 422-442.

Dulaurier,R. (1845). Chrestomathie Malaye, Letters et Piece Diplomatiques. Paris : Didot.

Fadhulullah, J. (1984). Perhubungan antara Kerajaan Aceh dengan Semenanjung Tanah Melayu. Satu tinjauan sejarah di sekitar abad ke-16 hingga abad ke-17 Masihi. Nusantara, 12, 37-58.

Gallop, A.T. (1994). Warisan Warkah Melayu. London: The British Library.

Gallop, A.T. (2018). What's in a name? Malay seals as onomastic sources. Malay Literature, 31(1), 128.

Hashim, M. (2004). Pemerkasaan Tamadun Melayu Malaysia: Menghadapi Globalisasi Barat. Kuala Lumpur: Penerbit Universiti Malaya dan Pusat Dialog Peradaban.

Isnariah, I., Khushairi, F., Abdul Rashid D.M.(2017). Hati Budi Melayu Dalam Warkah Melayu Lama. Jurnal Sultan Alauddin Sulaiman Shah, 4(2), 1-16.

Keith, H., \& Richard, L. (2010). The Practice of Diplomacy: Its Evolution, Theory and Administration (2nd ed). London: Routledge.

La, N. (1996). Surat-surat Kerajaan Buton dari Abad XVII-XIX (Aspek Kebahasaan dan Komponen

Surat). Jurnal Filologi Melayu, 5, 93-98.

Mahfuzah, Y. (1994). Warisan Warkah Melayu. Dewan Budaya, 10, 52-53. 
INTERNATIONAL JOURNAL OF ACADEMIC RESEARCH IN BUSINESS AND SOCIAL SCIENCES

Vol. 8, No. 8, August 2018, E-ISSN: 2222-6990 @ 2018 HRMARS

Mohd Jamil, M. (2011). Sejarah Hubungan Diplomasi Kerajaan Melayu: Satu Tinjauan. Jurnal IKSEP, 2 , 71-90.

Mu'jizah. (2009). Iluminasi dalam surat-surat Melayu abad ke-18 dan ke-19. Jakarta: Kepustakaan Populer Gramedia.

Muhammad, Y. H. (1992). Pensejarahan Melayu: Kajian Tentang Tradisi Sejarah Melayu Nusantara. Kuala Lumpur: Dewan Bahasa dan Pustaka dan Kementerian Pendidikan Malaysia.

Noor Suraya, A. (2008) . Perubahan Bahasa dalam Warkah Diraja Melayu: Suatu Kajian Mengenai Surat-surat kepada Gabenor dalam Tahun 1786-1794 dan 1886-1894. Masters Dissertation. Kuala Lumpur: University of Malaya.

Normaisarah, O. (2015). Diplomasi Nabi Muhammad Saw Dalam Dakwah Baginda Di Luar Madinah. Bangi : Universiti Kebangsaan Malaysia.

Nurjamily, W. O. (2015). Kesantunan Berbahas Indonesia dalam Lingkungan Keluarga. Jurnal Humanika, 15 (3), 1-18.

Saiful B., K. (2015, 25 Februari). Kajian Terhadap Persuratan Melayu Zaman Silam Perlu Diitingkatkan. Berita Kampus UKM. Retrieved from http://www.ukm.my/news/arkib/index.php/ms/beritakampus/2021-call-to-step-up-study-on-historical-malay-letters-.html.

Salmah, J. N. Muhammad. (2017). Kerencatan Hubungan Diplomatik Kesultanan Melayu Melaka, Johor dan Aceh. MANU, 25, 107-136.

Salmah, J. N. Muhammad. (2017) . "Pengenalan Penyelidikan Ilmu Diplomatik dalam Warkah Melayu", in Bengkel Penyelidikan Manuskrip Alam Melayu. Institut Alam dan Tamadun Melayu, Universiti Kebangsaan Malaysia, Bangi. 21-22 Mac.

Siti Mariani, S. M. Omar. (2001). "Warkah Raja-Raja Melayu di Pusat Manuskrip Melayu”, in Bengkel Kajian Naskhah Kesultanan Melayu. Hotel Quality, Kuala Lumpur. 2-5 Julai.

Syed, M. N. al-Attas. (1972). Islam Dalam Sejarah dan Kebudayaan Melayu. Bangi: Universiti Kebangsaan Malaysia.

Tika, D.P. ( 2017) Relevansi Penyusunan Teori Diplomasi Dalam Perspektif Islam. Islamic World and Politics. 1 (1), pp. 111-126.

Wan, R. M., Osman \& Hamidah A. W. (2018) Kesantunan Berbahasa Kaunselor Pelatih dalam Sesi Kaunseling. GEMA Online ${ }^{\circledast}$ Journal of Language Studies Volume, 18(1), pp.252-269. Accessed from http://doi.org/10.17576/gema-2018-1801-15

Wang, Y. B. (2009). Diplomacy: Theory and Practice in Islam. Kuala Lumpur: Universiti Islam Antarabangsa. 